\title{
BUDAYA ORGANISASI, BUDAYA KERJA DAN PENGARUHNYA DALAM PRAKTIK MANAJEMEN
}

\author{
Oleh : \\ Didi Wahyu Sudirman \\ FIS UNY
}

\section{Abstrak}

Sebagai kepribadian suatu organisasi maka budaya organisasi memiliki sistem, pola-pola nilai, simbul-simbul dari praktik yang berkembang sepanjang usia organisasi yang bersangkutan. Budaya organisasi dibentuk oleh nilai-nilai individu dan nilai-nilai hakekat yang berkaitan satu sama lain dan berdampak positif timbuinya praktik-praktik budaya organisasi yang juga dipengaruhi oleh sikap, perilaku individu dan sikap perilaku kolektif.

Berkembangnya budaya organisasi karena adanya pengaruh sikap kerja, perilaku kerja dan hasil kerja individu/karyawan dan pengaruh akumulatif membentuk suatu budaya kerja. Budaya kerja merupakan sikap hidup yang didasari oleh nilai pandangan hidup yang telah menjadi sifat, kebiasaan dan kekuatan pendorong yang membudaya dalam kehidupan suatu kelompok/masyarakat/organisasi yang tercermin dalam perilaku, kepercayaan yang terwujud sebagai kerja atau bekerja.

Apabila budaya kerja ini dikembangkan dalam proses manajemen akan menumbuhkan sikap yang berorientasi pada tanggung jawab kelompok, kesediaan partisipasi/koordinasi, kesadaran kelompok, saling menghargai dan komitmen kerja. Akan tetapi dalam praktik, masih ada hambatan-hambatan dalam pengembangan budaya organisasi dan budaya kerja karena sikap dan perilaku negatif. Walaupun demikian dengan komitmen manajemen yang tinggi dan esensi kepemimpinan yang sadar akan perlunya pengembangan kelompok, maka hal tersebut bisa diatasi dengan kemampuan menemukan kesesuaian, keselarasan antara hubungan kebutuhan pribadi anggota organisasi dengan kepentingan organisasi.

Kata kunci: budaya organisasi, budaya kerja, komitmen manajemen.

\section{Pendahuluan}

Hambatan-Hambatan yang sering muncul dalam praktik manajemen bukan pada sistemnya tapi dipengaruhi oleh faktor manusia, bu- daya organisasi dan termasuk didalamnya lingkungan, organisasi. Hal ini akan sangat berpengaruh pada keleluasaan manajerial. Karena adanya keterbatasan ini dampaknya 
akan berpengaruh pada budaya kerja yang menyangkut sumber daya manusianya.

Dalam konteks kehidupan setiap individu mempunyai sesuatu yang dikenal dengan istilah kepribadian. Kepribadian seseorang/individu itu terdiri dari totalitas yang merupakan rangkaian ciri-ciri yang relatif tetap dan mantap. Seseorang/individu sering dikenal dengan berbagai ciri khasnya misalnya ramah, sopan, rajin merupakan gambaran ciri-ciri kepribadian individu. Dalam hal ini sebuah organisasipun memiliki kepribadian yang kita kenal dengan istilah budaya.

Budaya yang kuat adalah budaya dengan nilai-nilai utamanya dipegang teguh dan dianut secara luas dan mempunyai pengaruh yang lebih besar terhadap pada karyawan. Dalam beberapa organisasi, terutama organisasi yang memiliki budaya kuat dari beberapa dimensi budaya tersebut seringkali menonjol dibandingkan lainnya dan mampu membentuk organisasi yang memiliki kekhasan atau citra tersendiri. Hal ini berpengaruh pula di kalangan anggota organisasi dalam melaksanakan pekerjaan mereka.

Dalam suatu organisasi berbagai cara yang dilakukan dalam praktik, para karyawan mempelajari budaya organisasi dengan memahami visi dan misi organisasi, sejarah perusahaan ataupun ritual organisasi, semboyan-semboyan, slogan-slo- gan, upacara-upacara lainnya yang kesemuanya untuk memberikan gabaran tentang budaya organisasi yang bersangkutan. Kebudayaan dalam aktivitas manajemen merupakan penyangga yang mampu mempengaruhi karyawan, khususnya para manajer. Kebudayaan-kebudayaan yang kuat inilah yang membatasi pilihan-pilihan yang pengambilan keputusan manajemen/seorang manajer dengan memberikan informasi, alternatif mana yang dapat diterima dan mana yang tidak.

Lingkungan umum/organisasi merupakan kekuatan-kekuatan yang mempunyai potensi untuk mempengaruhi organisasi, walaupun relevansinya tidak begitu jelas. Kecuali, lingkungan khusus yang merupakan bagian lingkungan yang secara langsung dan relevan dengan pencapaian sasaran-sasaran organisasi. Berbagai dimensi juga ikut berperan dalam budaya organisasi dan secara tidak langsung, dalam proses manajemen akan membentuk budaya kerja di lingkungan organisasi tersebut yang mampu membentuk kepribadian, tingkah laku dan hasil kerja karyawan. Dampak positif lainya menumbuhkan etos kerja masing-masing individu anggota organisasi.

Budaya Organisasi dalam Praktik Organisasi 
Berbagai kajian tentang budaya organisasi pada dasarnya dimaknai dengan pemahaman bahwa dengan istilah tersebut, untuk menggambarkan adanya suatu sistem pemahaman bersama yang dianut oleh anggota-anggota yang membedakan organisasi tersebut dengan organisasi-organisasi yang lain. Makna tersebut mewakili persepsi bersama yang dianut oleh anggota-anggota organisasi yang bersangkutan. Demikian halnya budaya-budaya yang ada dalam suatu negara, suku dan adat-istiadat daerah memiliki aturanaturan baku disertai larangan-larangan yang menentukan bagaimana para anggota akan bertindak terhadap orang lain atau dalam lingkungan kelompoknya ataupun terhadap orang luar.

Setiap organisasi memiliki budaya-budaya yang menentukan bagaimana anggota-anggotanya harus berperilaku. Jadi disetiap organisasi terdapat sistem, pola-pola nilai, tatanan dan praktik-praktik sikap dan perilaku yang berkembang dari waktu

Gambar 1. Keselarasan Nilai - Pembentuk Budaya Organisasi ke waktu sepanjang organisasi tersebut tumbuh dan berkembang. Budaya organisasi dibentuk oleh nilainilai individu dan nilai kolektif yang berkaitan satu sama lain dan berpengaruh positif timbulnya praktik-praktik budaya organisasi yang dipengaruhi oleh sikap, perilaku individu dan sikap, perilaku kolektif. Hal ini timbulnya karena adanya unsur berbasis kepercayaan yang mampu mengkontrol perilaku individu-individu atau anggota-anggota organisasi.

Dari sudut pandang tata nilai organisasi, budaya organisasi terbentuk oleh citra diri dan perilaku positif karyawan. Di samping itu bǘdaya organisasi juga terbentuk oleh sikap dan perilaku individu yang secara bersama dari akumulasi perilaku ter-sebut membentuk hasil kerja berupa kinerja organisasi. Dalam kaitan ini Nugroho Ananto (2005:24) membe-rikan gambaran tentang keselaran nilai pembentukan budaya organi-sasi seperti ilustrasi berikut di bawah ini:

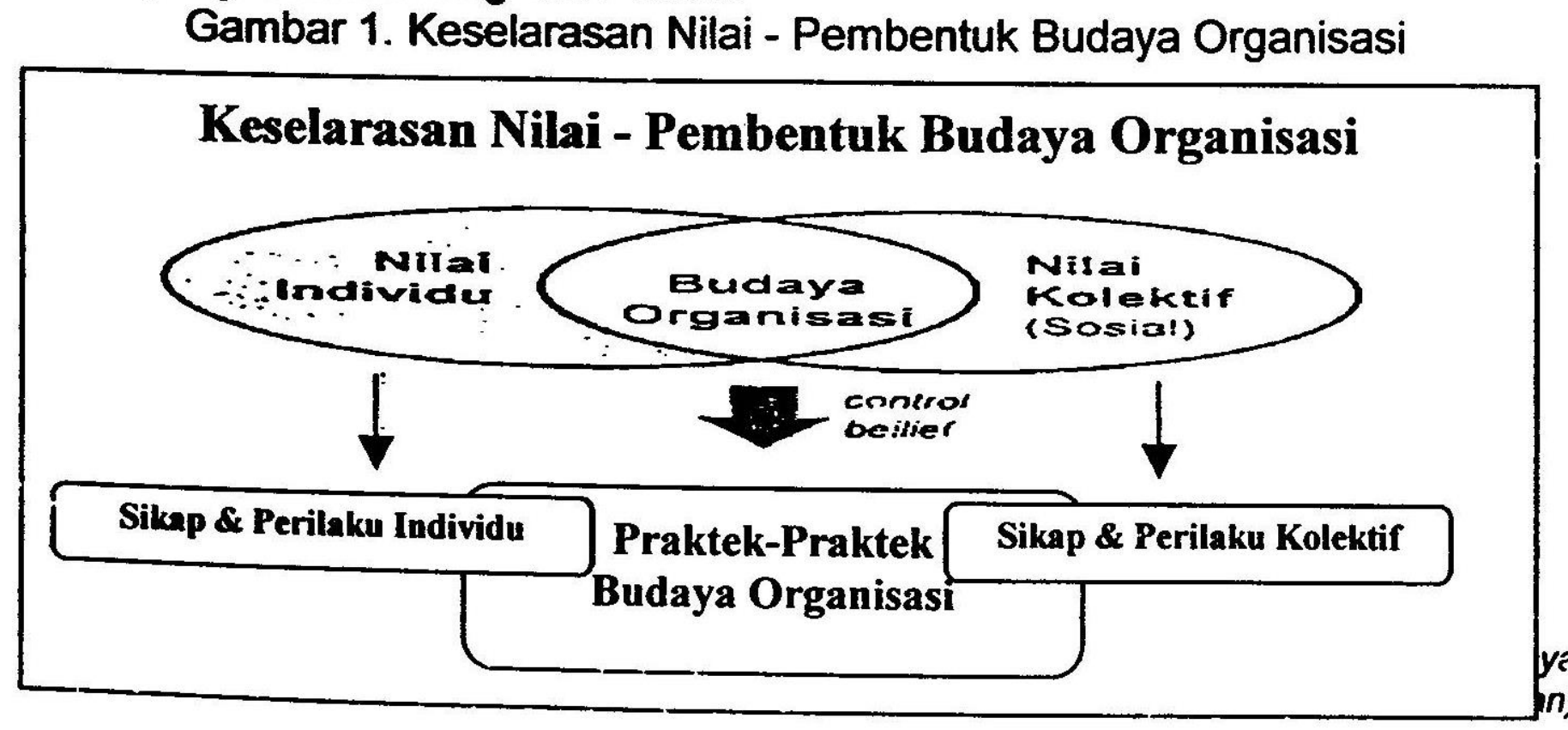


Berdasarkan kajian dan konsep tersebut di atas dapat disimpulkan bahwa:

1.Budaya organisasi adalah kristalisasi dan keyakinan, tata nilai, cara menyikapi suatu kondisi atau permasalahan dari seluruh anggota dalam semua tingkatan

2. Budaya organisasi adalah suatu sistem yang kompleks yang merupakan gabungan tata nilai, cara pandang, keyakinan dan peri- laku kolektif yang terbentuk dari sekumpulan orang (organisasiorganisasi)

3. Budaya organisasi merupakan gambaran/citra diri dan perilaku positif karyawan yang membentuk hasil kerja maupun kinerja organisasi/manajemen

Nugroho Ananto (2005:26) juga memberikan gambaran tentang elemen dasar pembentuk budaya organisasi sebagai berikut:

\section{Elemen Dasar Pembentuk Budaya Organisasi}

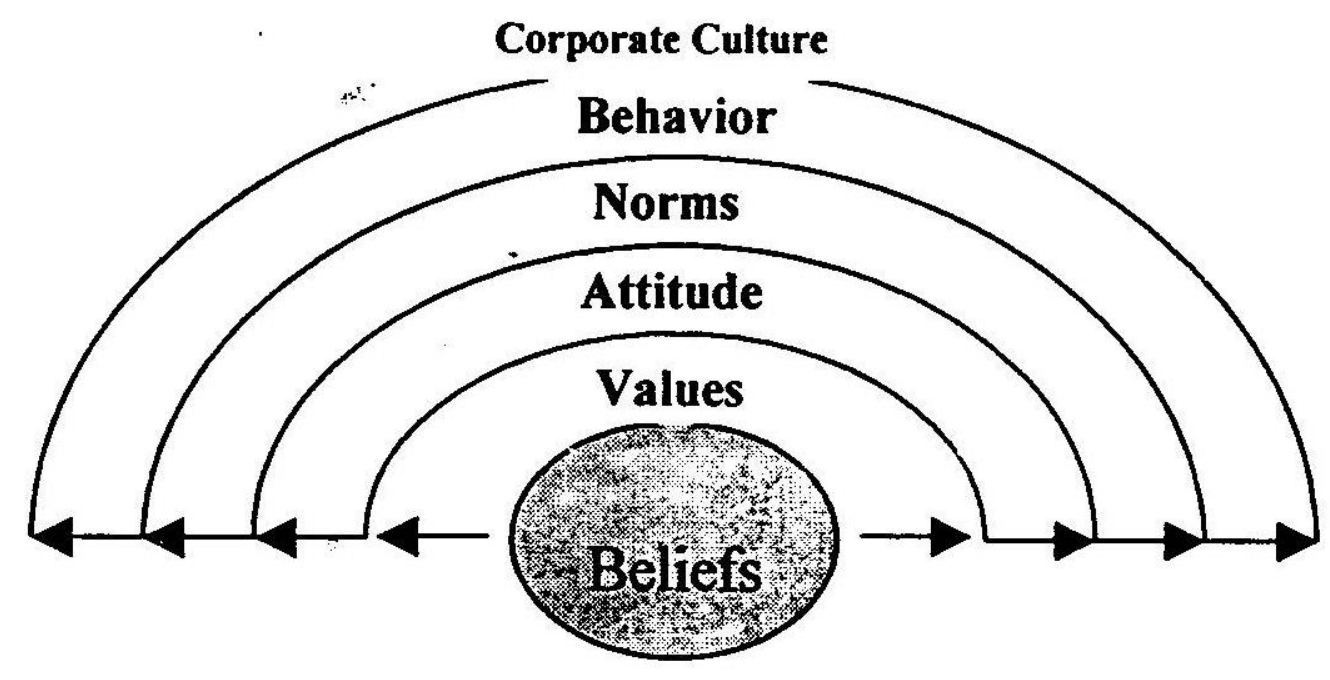

Gambar 2. Elemen Dasar Pembentukan Budaya Organisasi

Dalam membangun dan mengembangkan budaya organisasi (corporate culture) memang harus dilandasi keyakinan dasar. Keyakinan dasar (belief) merupakan wujud tingkat kepercayaan seseorang/indi- vidu. Dari keyakinan dasar inilah seseorang mampu memahami nilai-nilai baik/buruk. Dan berdasarkan persepsi tersebut maka individu yang bersangkutan memiliki sikap, kemudian membentuk norma-norma yang 
menjadi perilaku individu (individual behavior).

Apabila proses ini berlangsung secara alami dan saling berkaitan kearah positif maka selanjutnya akan membentuk budaya organisasi. Oleh karena itu manajemen dalam upaya mengembangkan budaya organisasi perlu menerapkan kepemimpinan berkualitas. Dalam kegiatan manajerial, praktik kepemimpinan bertujuan: meningkatkan performansi sumber daya (manusia, mesin, peralatan dan lain-lain); memperbaiki kualitas kerja yang ada secara berkesinambungan, meningkatkan output dan produktivitas; menciptakan kebanggaan kerja bagi karyawan/anggota organisasi/ perusahaan

Untuk mencapai tujuan tersebut diatas perlu diimbangi dengan berbagai cara dengan:

1.Kualitas kepemimpinan yang peka terhadap perubahanperubahan baik internal maupun eksternal.

2. Mengkomunikasikan visi dan misi perusahaan

3. Mencipiakan kultur positif dan iklim harmanis dan kondusif dalam perusahaan/organisasi

4. Menciptakan tanggung jawab dan pemberian wewenang (empowerment)

5. Melaksanakan komitmen perbaikan kualitas kerja secara terus menerus
Budaya Kerja Dalam Organisasi

Mata rantai dampak positif dari budaya organisasi yaitu adanya pengaruh sikap kerja, perilaku kerja dan hasil kerja dari karyawan. Sikap kerja yang dimaksud adalah pola pikir, pendirian, perasaan atau emosional yang mendasari suatu tindakan dalam setiap mengawali dan menyelesaikan suatu pekerjaan. Mengenai perilaku kerja merupakan perbuatan, tindakan atau kebiasaan dan keterampilan kerja yang ditunjukkan dalam proses (keseharian) bekerja. Sedangkan hasil kerja atau prestasi adalah fakta dalam kualitas maupun kuantitas yang dicapai dari prestasi sejak mengawali sampai dengan selesainya suatu pekerjaan.

Pengaruh akumulatif budaya organisasi ini pada karyawan membentuk suatu budaya kerja. Budaya kerja dalam proses manajemen, berorientasi pada sumber daya manusia dengan prinsip kelompok/tim dan antara kelompok/tim yang memiliki/ saling ketergantungan baik secara vertikal maupun horizontal

Budaya kerja dapat juga dipahami menurut konsep Menteri $\mathrm{Ne}$ gara Pendayagunaan Aparatur $\mathrm{Ne}$ gara: Sikap hidup yang didasari oleh nilai pandangan hidup yang telah menjadi sifat, kebiasaan dan kekuatan pendorong yang membudaya dalam kehidupan suatu kelompok masyarakat/organisasi yang kemudian tercermin dalam perilaku, kepercayaan, cita-cita, pendapat dan tin- 
dakan yang terwujud sebagai kerja atau bekerja (1998:2)

Bagi individu budaya kørja merupakan dorongan untuk berproduksi untuk menghasilkan yang terbaik dalam kerja sesuai dengan kemampuannya. Seseorang akan dapat menghayati pekerjaan atau kegiatannya bila dia mengerti bagaimana pandangan terhadap bekerja, kebiasaatnya dalam kerja dan kelompok kerjanya. Kerja seperti ini akan membentuk latar belakang serta dasar bagi individu/manusia dalam mengembangkan kepribadiannya.

Kalau diperhatikan aspek individu dalam mengembangkan kepribadiannya di dalam budaya kerja organisasi perlu juga memperhatikan aspek-aspek dari dalam dan luar manusia/individu itu sendiri.

Aspek-aspek tersebut adalah:

a. Memberikan kesempatan kepada individu untuk mengembangkan dan memanfaatkan kemampuannya.

b. Manusia bekerja untuk menghasilkan (barang atau jasa) yang diperlukan bagi kehidupan manusia

c. Mengendalikan dan mengatasi kecenderungan bersifat egois/ egosentris diri pribadi dengan cara ikut serta bersama orang lain untuk melakukan tugas/pekerjaan bersama dalam kelompok/tim.

Dari berbagai ulasan tersebut di atas, implikasinya adalah individu- individu menyerap budaya kerja tersebut berdasarkan apa yang mereka lihat, rasakan dan dengar dalam kehidupan organisasi. Jadi meskipun individu-individu memiliki latar belakang yang berbeda atau bekerja pada tingkat-tingkat yang berbeda atau berlainan dalam organisasi, mereka cenderung menggambarkan budaya kerja dengan pemahaman atau istilah-istilah yang sama. Bagaimanapun juga para anggota organisasi atau individu-individu melihat organisasi tersebut, bukan mengenai apakah mereka menyukainya atau tidak, akan tetapi pada komitmen individu masing-masing. Dengan demikian budaya kerja adalah menggambarkan dan bukan menilai.

Di samping itu perlu juga diperhatikan bahwa budaya kerja mempunyai manfaat:

a. Menjamin hasil kerja dengan kualitas/mutu baik

b. Membuka seluruh komunikasi, keterbukaan, cepat menemukan kesalahan dan cepat memperbaikinya.

c. Cepat menyesuaikan diri dengan perkembangan dari luar.

d. Mengurangi laporan salah/palsu

Selanjutnya (1998:3) dijelaskan mengenai tujuan budaya kerja adalah: manusia Indonesia harus memiliki sifat antara lain tangguh, cerdas, terampil, mandi, i, memiliki rasa kesetiakawanan, kerja keras, hemat, produktif, berdisiplin serta 
berorientasi masa depan untuk menciptakan kehidupan yang lebih baik (1998:2).

Apabila budava kerja ini dikembangkan/dilaksanakan dalam proses manajemen maka yang perlu diiplementasikan dalam budaya kerja adalah sebagai berikut:

a. Selalu berorientasi tanggung jawab kelompok

b. Kesediaan partisipasi/koordinasi

c. Kesadaran kelompok yang dinamis dan harmonis

d.Saling menghargai golongan/ tingkatan

e.Komitmen kerja dan integritas yang tinggi

f. Perbaikan dan pembelajarran terus menerus

g.Kepercayaan dan saling menghormati

h. Kejujuran dan kreativitas

i. Mendahulukan kepuasan dan kepentingan pelanggan

j. Kepemimpinan yang efektif

k. Kepedulian terhadap lingkungan hidup

Kendala Pengembangan Budaya Organisasi Budaya Kerja

Berbagai kajian yang telah membahas mengenai budaya organisasi, budaya kerja memperhatikan bahwa kedua hal tesebut sangat penting, strategis untuk selaku dikembangkan dan merupakan komitmen manajemen. Karena disadari atau tidak, bahwa ada faktor-faktor lain yang dapat mempengaruhi pe- ngembangan budaya organisasi, budaya kerja dalam proses manajemen. Beberapa contoh yang dikemukakan oleh Nugroho Ananto (2005:30) mengemukakan sikap dan perilaku negatif menjadi kedala pengembangan budaya organisasi, sebagai berikut:

a. Diskriminatif

b. Tidak efisien dan efektif

c. Tidak menghormati hak asasi manusia

d. Kurang menghormati sesama

e. Kurang tanggap

f. Tidak kreatif dan inovatif

g. Tidak peduli, tidak acuh

h. Sikap konfrontatif berlebihan, sering menentang tidak kooperatif

i. Kurang menghargai perbedaan pendapat

j. Etos kerja rendah

k. Sering mengeluh secara berlebihan

I. Sikap tidak terbuka dan tidak jujur

$m$. Kurang inisiatif menunggu perintah

Selanjutnya dalam budaya kerja yang menjadi kendala adalah sikap negatif meliputi:

a. Meremehkan mutu

b. Suka jalan terobosan/pintas

c. Tidak percaya diri

d. Tidak disiplin

e. Mengabaikan tanggung jawab

f. Tidak bermotivasi kemajuan

g. Tidak menghargai waktu

h. Tidak memperhitungkan biaya

i. Tidak menghargai atasan 
j. Tidak menghargai bawahan

k. Tidak menghargai sesama karyawan/n zgawai (1998:13)

Dari berbagai kendala tersebut dalam pengembangan budaya organisasi, budaya kerja maka manajemen perlu melakukan terobosan ataupun membangkitkan dan mendayagunakan sumber daya mental spriritual untuk membangun budaya organisasi, budaya kerja yang mampu membangun masa depan melalui kekuatan visi dan misi organisasi yang motivatif. Jansen Sinamo dalam bukunya Strategi Adaptif Abad 21 menyatakan bahwa ada tiga aspek penting yang perlu dibangun yaitu: Pertama, visi misi yang dirumuskan mengandung sis intelektual dan sisi emosional secara seimbang. Ini penting karena keyakinan ditambah motivasi akan berubah menjadi kekuatan; kedua, visi misi harus di dukung secara serasi dan sepandan oleh nilai-nilai dasar (core values) yang menjadi panduan perilaku utama (key behavior) yang konsisten menuju visi dari misi tersebut; ketiga, visi-misi harus didukung oleh strategi bisnis dan system manajemen yang serasi dan sepadan pula; Ketiga, komponen tersebut akan membentuk irisan yang dapat kita sebut sebagai budaya kerja yang antara lain mengandung etos kerja (2000:144)

Dengan munculnya nilai-nilai dasar maka akan muncul pula kesadaran kualitas yang berdampak pada produktivitas kerja. Dalam proses berikutnya peranan manajer sangat dibutuhkan dalam upaya meningkatkan dan mengembangkan kualitas individu/karyawan. Peranan manajer tersebut dalam hal melakukan perubahan perilaku, penetapan kebutuhan, pengukuran perfomansi kualitas serta penetapan dan peningkatan sasaran kualitas yang diharapkan sesuai dengan visi dan misi perusahaan/organisasi.

Manajer dalam mengembangkan budaya organisasi, budaya kerja diharapkan memiliki kemampuan memberdayakan orang lain. Kemampuan tersebut merupakan esensi kepemimpinan yang mampu melibatkan potensi individu/karyawan untuk secara bersama-sama melakukan perubahan menuju budaya kerja yang berkualitas.

Menurut pendapat Azhar Arsyad (2002:147) bahwa keberhasilan suatu perubahan ada tiga pelaku perubahan yang bisa berperan dalam setiap proses perubahan:

Para pelaku perubahan dengan kekuasaan resmi (legitimacy of change) adalah mereka vang memiliki kekuasaan yang diakui secara formal dan sah.

Para pendorong dan penganjur timbulnya perubahan (instigators of change) adalah mereka yang memandang perlunya perubahan karena telah membandingkan dan melihat sesuatu yang baik di tempat lain

Para fasilitator perubahan ( $f a-$ cilitators of change) adalah mereka 
yang memiliki kewibawaan dan diakui serta dikenal sebagai pemimpin informal yang memudahkan serta melicinkan proses timbulnya perubahan.

Sebagai pelaku perubahan, manajer memerlukan penguasaan leadership dan managerial skill. Manajerial dibutuhkan untuk melakukan analisis rasional terhadap proses perencanaan, leadership dibutuhkan untuk memicu dan memacu perubahan yang telah direncanakan kemudian tugas manajerial yang melakukan penyelarasan perubahan yang dipacu tersebut, (Didi Wahyu Sudirman, dkk., 2004:13). Oleh karena itu peranan manajer saat ini sudah perlu dibenahi. Tugas-tugas seperti koordinasi, pengawasan, control dapat didelegasikan kepada para pembantu atau asisten yang memiliki kompetensi dan dapat dipercaya. Manajer sebagai pemimpin perlu membentuk tim sebagai pelaku perubahan untuk memacu pengembangan budaya kerja dengan perbaikan berkesinambungan. Manajer juga harus mampu membangun budaya yang menunjang pengembangan diri individu/karyawan, mampu berkomunikasi intensif untuk mendapatkan follow-up atau feedback serta kemampuan menemukan kesesuaian, keselarasan antara hubungan pribadi anggota organisasi dengan kebutuhan organisasi

Memang dalam kenyataannya sering terjadi bahwa usaha memba- ngun budaya organisasi, budaya kerja dan memberdayakan sumber daya manusia kadang-kadang mengalami kegagalan. Hal ini disebabkan oleh faktor kurangnya dukungan dan komitmen manajemen. Oleh karena itu manajemen hendaknya perlu menyadari arti pentingnya bahwa memberdayakan sumberdaya manusia merupakan salah satu langkah strategis yaitu dengan cara melakukan perubahan melalui pemberdayaan sumber daya manusia.

Usaha-usaha memberdayakan sumber daya manusia/individu-individu dalam proses manajemen organisasi juga merupakan suatu perubahan budaya. Pemberdayaan tidak akan tumbuh dan berkembang atau berjalan semestinya, apabila seluruh komponen yang berpotensi membangun budaya organisasi dan budaya kerja tidak berubah secara mendasar. Oleh sebab itu hendaknya manajemen perlu dan harus mampu melakukan berbagai macam pendekatan atau strategi yang bisa mendorong setiap individu/karyawan diseluruh tingkatan dalam organisasi untuk ikut berpartisipasi aktif melakukan perubahan, sekaligus secara simultan menumbuhkan budaya organisasi, budaya kerja di lingkungan organisasi. Jadi meningkatkan budaya kerja dengan cara meningkatkan kualitas sumber daya manusia dan meneruskan organisasi yarig sehat. 


\section{Penutup}

Memperhatikan berbagai kajian menge rai kebudayaan menyiratkan beberapa bahwa kebudayaan merupakan persepsi dan merupakan istilah deskriptif. Dari keseluruhan hakikat budaya sebuah organisasi ada beberapa aspek yang perlu menjadi gambaran dengan perlu menjadi gambaran dalam sebuah kontinum dari derajat rendah sampai tinggi. Dimensi-dimensi budaya organisasi tersebut digambarkan sebagai berikut:

1. Selalu memberi perhatian pada detail, sebagai contoh tingkatan para karyawan diharapkan untuk menunjukkan ketepatan, analisis dan perhatian terhadap detail.

2. Orientasi pada tim, yaitu ting- katan kegiatan-kegiatan kerja disusun oleh tim-tim dan bukan individu-individu

3. Agresivitas yaitu tingkatan individu-individu pada umumnya bersifat agresif dan bersaing secara sehaat dan objektif.

4. Orientasi hasil, yaitu tingkatan yang memperlihatkan para manajer memusatkan perhatian pada hasil-hasil dan bukannya pada teknik-teknik dan proses-proses yang digunakan untuk mencapai hasil-hasil tersebut.

5. Orientasi pada manusia, yaitu tingkatan dalam hal keputusan-keputusan manajemen de- ngan memperhitungkan pe. ngaruh hasil-hasil terhadap manusia di dalam organisasi.

6. Kemampuan inovasi dan mengambil resiko, yaitu tingkatan dari aktivitas karyawan, didorong untuk bersikap motivatif, kemampuan dan keberanian mengambil resiko

7.Stabilitas, yaitu tingkatan dalam hal kegiatan-kegiatan organisasi menekankan usaha mempertahankan kestabilan organisasi agar tetap olid unuk berkembang.

Dengan memperhatikan berbagai ulasan di atas maka untuk menilai organisasi dari aspek dimensidimensi tersebut, akan diperoleh suatu gambaran majemuk tentang budaya dalam organisasi. Dalam hal ini kebudayaan dapat dikatakan membatasi para manajer sebab kebudayaan bertindak sebagai filter otomatis yang bisa membelokkan persepsi, pikiran perasaan-perasaan manajer tersebut. Kebudayaan-kebudayaan kuat terutama membatasi pilihanpilihan pengambilan keputusan manajemen dengan memberitahukan alternatif mana yang dapat diterima dan mana yang tidak.

Di samping itu budaya yang kuat adalah budaya yang nilai-nilai utamanya dipegang teguh dan dianut secara luas dan mempunyai pengaruh yang lebih besar terhadap para karyawan, disbanding kebudayaan-kebudayaan yang lemah. Dari 
kebanyakan organisasi, teruta-ma organisasi yang memiliki budaya kuat, salah satu diantara dimensidimensi budaya itu sering menonjol di atas semua yang lain dan membentuk gambaran organisasi tersebut serta cara para anggota organisasi, melakukan pekerjaan mereka.

Mengembangkan sebuah budaya organisasi, budaya kerja yang mendukung keragaman memang sering sulit dan mengalami kendala. Akan tetapi ke depan akan memberikan manfaat-manfaat potensial yang tinggi. Organisasi-organisasi seperti digambarkan tersebut di atas dan organisasi pada umumnya telah banyak menemukan cara-cara untuk menyusun kebijakan dan praktikpraktik yang memungkinkan tumbuh dan berkembangnya keragaman. Organisasi-organisasi tersebut tidak melihat perubahan-perubahan budaya atau lingkungan sebagai kendala, melainkan sebagai peluang yang menjanjikan.

\section{Daftar Pustaka}

Azhar Arsyad, Prof., Dr., MA., 2002.

Pokok-Pokok Manajemen (Pengetahuan Praktis Bagi Pimpinan dan Eksekutif), Yogyakarta: Pustaka Pelajar
Didi Wahyu Sudirman, Drs., M.M., dkk., 2004. Supervisory Development Program (Materi Pelatihan Manajer dan Eksekutif), Yogyakarta: PT WISH, Consultant \& Training Specialist.

Jansen Sinamo, 2000. Strategi Adaptif Abad - ke 21, Berselancar di Atas Gelombang Krisis. Jakarta: Penerbit PT Gramedia Pustaka Utama

Menteri Pendayagunaan Aparatur Negara, 1998. Budaya Kerja. Jakarta: Kantor Menteri Pendayagunaan Aparatur Negara

Nugroho Ananto, Ir., M.Eng., M.M., 2005. Peningkatan Kinerja dan Pengembangan SDM Profesional (Kiat Sukses Dalam Mengatasi Hambatan). Bandung Sinergi Managing Partner Sinergi Consulting.

\section{Biodata Penulis}

Drs. Didi Wahyu Sudirman, MM., Staf pengajar pada Program Studi Pendidikan Administrasi Perkantoran, Fakultas IImu Sosial, Universitas Negeri Yogyakarta 